Ruixia Liu $\cdot$ Baowen Zhang $\cdot$ Hongxiao Tang

\title{
Dynamic adsorption and desorption of heavy metal ions on poly(acrylaminophosphonic-carboxyl-hydrazide) chelating fiber
}

Received: 15 October 1997 / Revised: 17 March 1998 / Accepted: 20 March 1998

\begin{abstract}
The dynamic adsorption and desorption properties, including the effect of $\mathrm{pH}$ value and flow rate on the adsorption, eluent acidity and volume, eluting velocity and re-use, of $\mathrm{Cu}(\mathrm{II}), \mathrm{Pb}(\mathrm{II}), \mathrm{Zn}(\mathrm{II}), \mathrm{Cd}(\mathrm{II}), \mathrm{Mn}(\mathrm{II}), \mathrm{Ni}(\mathrm{II})$, $\mathrm{Co}$ (II) and $\mathrm{Hg}$ (II) ions on the column loaded with poly(acrylaminophosphonic-carboxyl-hydrazide) chelating fiber were investigated. The recovery of $\mathrm{Mn}(\mathrm{II})$, $\mathrm{Co}(\mathrm{II}), \mathrm{Cd}(\mathrm{II}), \mathrm{Ni}(\mathrm{II})$ and $\mathrm{Zn}(\mathrm{II})$ ions in the presence of $\mathrm{Na}, \mathrm{K}, \mathrm{Ca}$ and $\mathrm{Mg}$ ions was examined. The preconcentration of trace amounts of $\mathrm{Mn}(\mathrm{II}), \mathrm{Co}(\mathrm{II}), \mathrm{Cd}(\mathrm{II}), \mathrm{Ni}(\mathrm{II})$ and $\mathrm{Zn}$ (II) ions from model solution samples was carried out with satisfactory results. The amount of the metal ions detected after preconcentration and recovery by this technique was basically in agreement with the added amount. The method is rapid, precise and simple.
\end{abstract}

\section{Introduction}

In analytical chemistry, the preconcentration process is of great importance since it enables trace elements to be determined in combination with different identification methods $[1,2]$. Sorption with chelating sorbents is very promising in this respect. The chelating resins have a high adsorption capacity for noble metals [3-8], but a slow sorption rate.

Fibrous sorbents hold great advantage for the concentration of microelements from natural waters. The large surface area and high kinetic properties of these sorbents and the possibility of using them in different sorption

R. Liu (凶) · H. Tang

State Key Laboratory of Environmental Aquatic Chemistry,

Research Center for Eco-Environmental Sciences,

Chinese Academy of Sciences, P.O.Box 2871

Beijing 100085, China,

e-mail: Rachel@mail.rcees.ac.cn

B. Zhang

Central Iron and Steel Research Institute,

Ministry of Metallurgical Industry, Beijing 100081, China modes, such as filters and films, make them useful to determine the concentrations of various microelements [9-11]. The chelating cellulose sorbents have recently been reported [12-17]. But owing to their poor performance in acid solution and lower sorptive capacity for metal ions, these sorbents cannot be widely applied. Although the poly(acrylamidoxime-carboxylic acid) chelating fiber has been developed for the concentration of multielements from various samples [18-20], the swelling effect of the fiber during elution limited its re-usability. Polyacrylacylisothiourea [21] and poly(acrylamidrazonehydrazide) chelating fibers [22] have been synthesized and applied to the concentration-separation of trace amounts of $\mathrm{Au}(\mathrm{III}), \mathrm{Pd}(\mathrm{IV}), \mathrm{Ru}(\mathrm{III})$ and $\mathrm{In}(\mathrm{III}), \mathrm{Sn}(\mathrm{IV})$, Cr(III), V(V), Ti(IV).

A new type of poly(acrylaminophosphonic-carboxylhydrazide) chelating fiber, called PAAP-II, was obtained through the following steps: 1) The polyacrylonitrile fiber was modified by hydrazine; 2) the hydrazine-modified fiber reacted with diethylenetriamine, and the aminated fiber was obtained; 3) the PAAP-II chelating fiber was prepared by introducing the phosphonic group into the aminated fiber. By infrared spectroscopic analysis, it was shown that the PAAP-II chelating fiber contained carboxyl, aminophosphonic and hydrazide groups. The synthesis and structure of the sorbent has been described in detail elsewhere [23].

However, the dynamic column adsorption and desorption properties of the poly(acrylaminophosphonic-carboxyl-hydrazide) chelating fiber have not been reported previously. In this report, we investigate the preconcentration efficiency of the newly developed chelating fiber for heavy metal ions by means of the dynamic adsorption technique. The adsorption properties, including effect of flow rate and $\mathrm{pH}$ value on adsorption, and desorption conditions such as elution velocity, desorption acidity, eluent volume and re-usability are discussed in detail. 
Fig. 1 Effect of flow rate on the adsorption of metal ions by PAAP-II chelating fiber
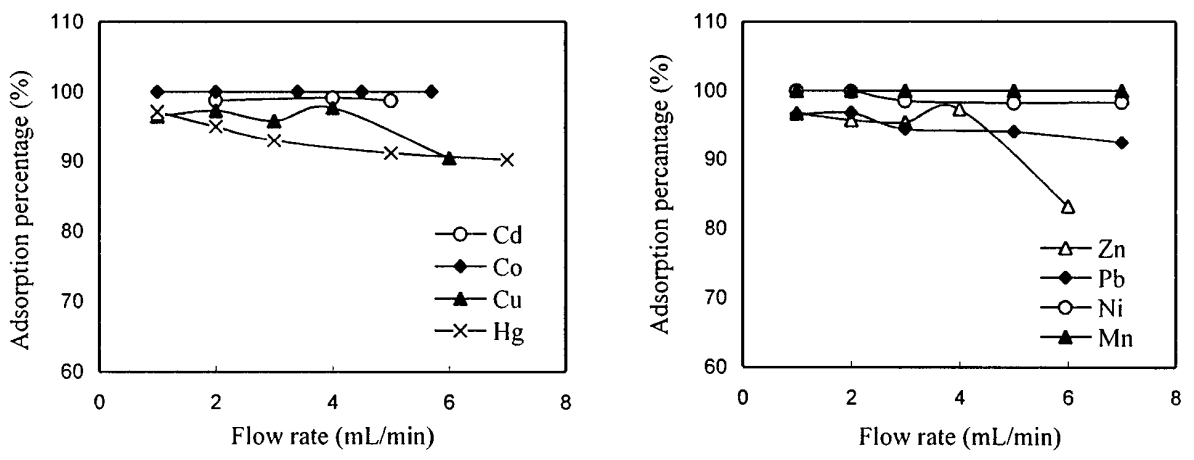

\section{Material and methods}

Reagents and standards

The poly(acrylaminophosphonic-carboxyl-hydrazide) chelating fiber was cut into $1 \mathrm{~mm}$ units, soaked in $1 \% \mathrm{NaOH}$ solution for 3-4 h, and then suction-filtered, washed with distilled water, and dried at $60-65^{\circ} \mathrm{C}$ overnight.

All chemicals were of analytical grade. Deionized water was used throughout the experimental procedure. The standard solutions (1000 mg/L) of $\mathrm{Cu}(\mathrm{II}), \mathrm{Pb}(\mathrm{II}), \mathrm{Zn}(\mathrm{II}), \mathrm{Cd}(\mathrm{II}), \mathrm{Mn}(\mathrm{II}), \mathrm{Ni}(\mathrm{II})$, $\mathrm{Co}$ (II) and $\mathrm{Hg}$ (II) were provided by Central Iron and Steel Research Institute, Ministry of Metallurgical Industry, China, and the test concentrations of these metal ions were further diluted to $2.0 \mathrm{mg} / \mathrm{L}$ prior to use.

\section{Instrument and apparatus}

A 3100 Enhanced Data System (Perkin-Elmer) and a Z-6100 (Hitachi) Atomic Absorption Spectrometer (AAS) were used for the determination of low and high concentrations of the single metal ions. The concentration of the mixed metal ions was determined by a Spectroflame ICP Argon-plasma Emission Spectrometer (Spectro Analytical Instruments Kleve, Germany). The $\mathrm{pH}$ values of the solutions were measured with a Model pHS-3 C pH-meter (Shanghai Instrument Company). Glass columns of $20 \mathrm{~cm}$ length and $1 \mathrm{~cm}$ inner diameter were used for dynamic adsorption experiments and preconcentration of the trace metal ions.

\section{Column adsorption procedure}

The fiber column, containing 0.25 g PAAP-II chelating fiber, was prepared by spiraling a water slurry of the chelating fiber. The bed height of sorbent in the column was $3 \mathrm{~cm}$.

A volume of $10 \mathrm{~mL}$ of $2 \mathrm{mg} / \mathrm{L} \mathrm{Cu}(\mathrm{II}), \mathrm{Pb}(\mathrm{II}), \mathrm{Zn}(\mathrm{II}), \mathrm{Cd}(\mathrm{II})$, $\mathrm{Mn}(\mathrm{II}), \mathrm{Ni}(\mathrm{II}), \mathrm{Co}(\mathrm{II})$ and $\mathrm{Hg}(\mathrm{II})$ single metal ion solutions, previously adjusted to the desired $\mathrm{pH}$ value with diluted $\mathrm{NH}_{4} \mathrm{OH}$ solution, was passed through the adsorption columns at flow rates of $1-8 \mathrm{~mL} / \mathrm{min}$. After the passage of the solutions, the columns were rinsed twice with $10 \mathrm{~mL}$ of deionized water. The concentrations of the metal ions in effluents were determined by AAS.

\section{Desorption experiments}

After the adsorption procedure, the adsorbed metal ions on the fiber column were eluted with different concentrations of diluted hydrochloric or nitric acid at eluting rates of $1-8 \mathrm{~mL} / \mathrm{min}$. The concentrations of metal ions were analyzed by AAS.

Re-use of the chelating fiber

A volume of $10 \mathrm{~mL}$ of a mixture containing $2 \mathrm{mg} / \mathrm{L}$ each of $\mathrm{Cd}(\mathrm{II})$, $\mathrm{Mn}(\mathrm{II}), \mathrm{Ni}(\mathrm{II}), \mathrm{Co}(\mathrm{II})$ and $\mathrm{Cu}(\mathrm{II})$, previously adjusted to $\mathrm{pH} 6.0 \pm$ 0.3 with diluted $\mathrm{NH}_{4} \mathrm{OH}$ solution, was added to the fiber column at
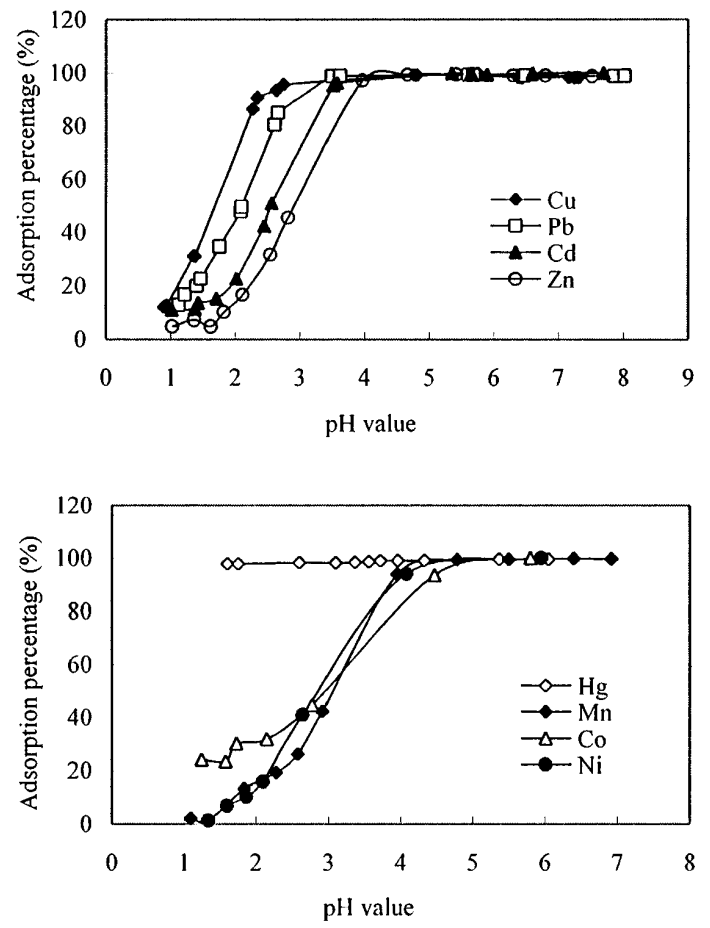

Fig. 2 Effect of $\mathrm{pH}$ value on the adsorption of metal ions by PAAP-II chelating fiber

a flow rate of $3 \mathrm{~mL} / \mathrm{min}$. The metal ions extracted by the sorbent were desorbed with $30 \mathrm{~mL}$ of $6 \mathrm{~mol} / \mathrm{L}$ hydrochloric acid at a flow rate of $2 \mathrm{~mL} / \mathrm{min}$. The column was rinsed twice with deionized water, then soaked in $1 \% \mathrm{NaOH}$ solution, and substantially washed with deionized water until neutrality was reached. As in the above process, the experiment was repeated 10 times. The adsorption and desorption percentages were calculated each time.

\section{Effect of interfering ions}

A mixture, containing $20 \mu \mathrm{g}$ each of $\mathrm{Zn}(\mathrm{II}), \mathrm{Cd}(\mathrm{II}), \mathrm{Mn}(\mathrm{II}), \mathrm{Ni}(\mathrm{II})$, $\mathrm{Co}$ (II) ions and $10-20 \mathrm{mg}$ each of $\mathrm{Na}, \mathrm{K}, \mathrm{Ca}, \mathrm{Mg}$ interfering ions in $100 \mathrm{~mL}$ solution at $\mathrm{pH} 6.0 \pm 0.3$, was passed through the PAAP-II fiber column at a flow rate of $3 \mathrm{~mL} / \mathrm{min}$. The concentrations of the metal ions eluted with $40 \mathrm{~mL}$ of $6 \mathrm{~mol} / \mathrm{L}$ hydrochloric acid were determined by ICP after the solution was concentrated to $50 \mathrm{~mL}$.

Preconcentration of trace metal ions from model solution samples

A $1 \mathrm{~L}$ mixing solution, containing 15-20 $\mu \mathrm{g} / \mathrm{L}$ each of $\mathrm{Zn}(\mathrm{II})$, $\mathrm{Cd}(\mathrm{II}), \mathrm{Mn}(\mathrm{II}), \mathrm{Ni}(\mathrm{II})$ and $\mathrm{Co}(\mathrm{II})$, was passed through PAAP-II chelating fiber column at a flow rate of $3 \mathrm{~mL} / \mathrm{min}$. The column was 
Fig. 3 Effect of eluent acidity and volume on desorption of (a) $\mathrm{Cd},(b) \mathrm{Co},(c) \mathrm{Cu},(d) \mathrm{Mn}$, (e) $\mathrm{Ni},(f) \mathrm{Pb},(g) \mathrm{Zn},(h) \mathrm{Hg}$ ions from PAAP-II chelating fiber column (eluting rate 2 $\mathrm{mL} / \mathrm{min}$ )

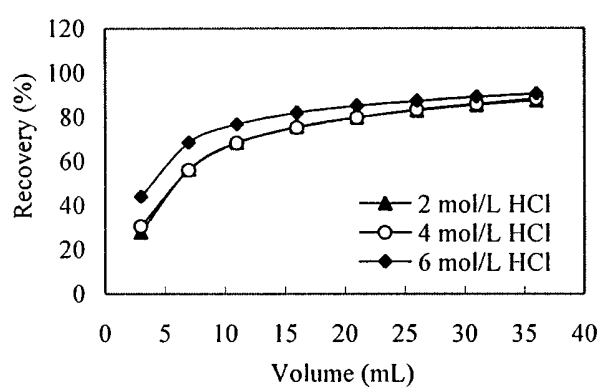

(a)

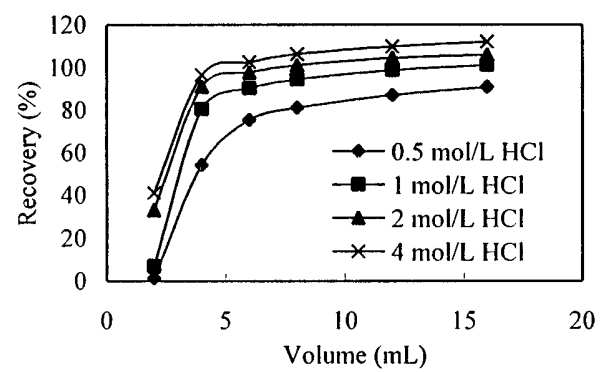

(c)

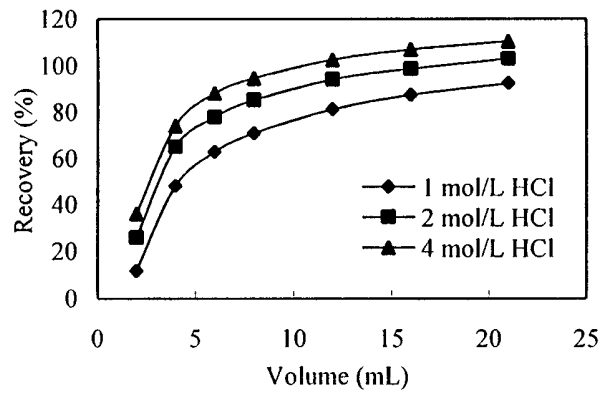

(e)

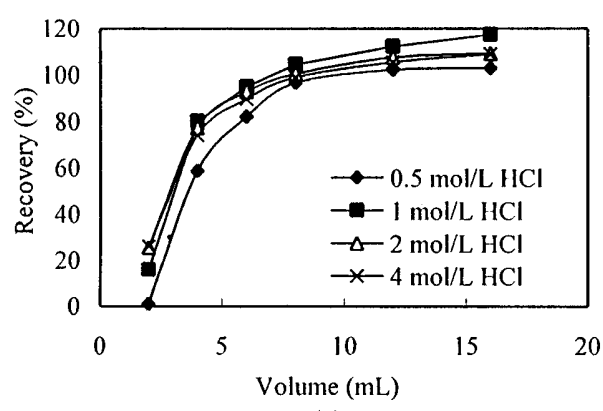

(g)

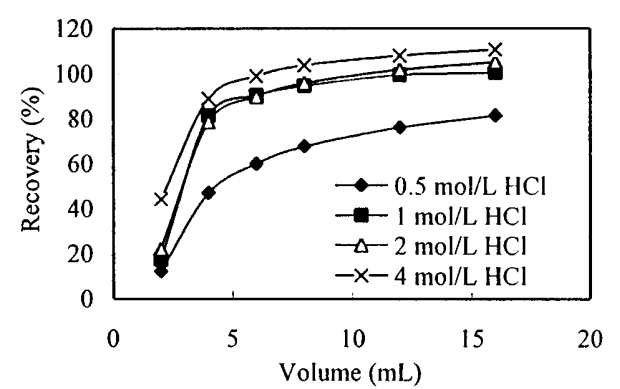

(b)

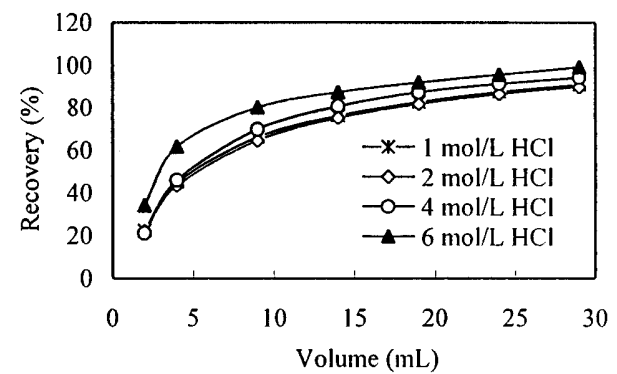

(d)

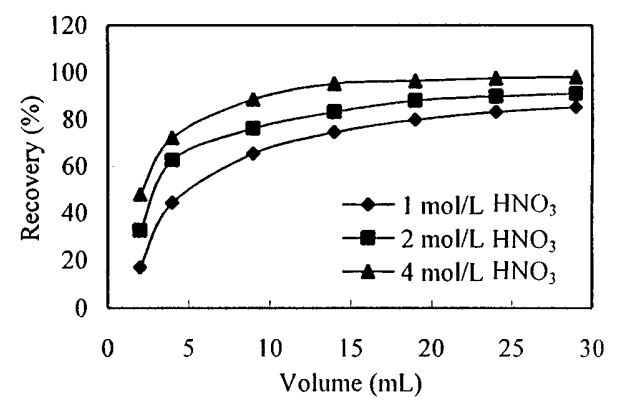

(f)

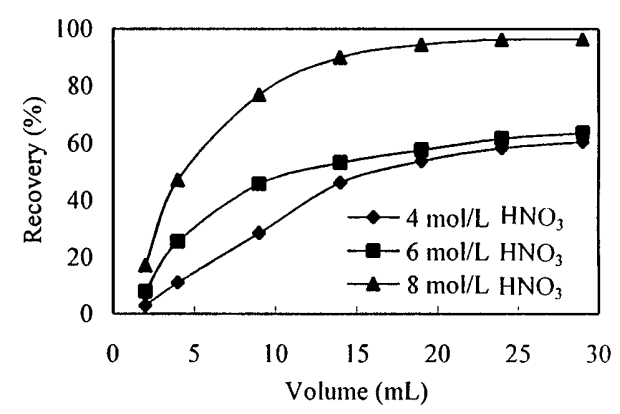

(h) washed twice with $10 \mathrm{~mL}$ of deionized water, and then the adsorbed metal ions were eluted with $40 \mathrm{~mL}$ of $6 \mathrm{~mol} / \mathrm{L}$ hydrochloric acid. The eluate was transferred to a $50 \mathrm{~mL}$ volumetric flask. The concentration of the eluted metal ions were determined by ICP.

\section{Results and discussion}

Effect of flow rate on the adsorption

Figure 1 presents the effect of the flow rate on the adsorption of metal ions by the poly(acrylaminophosphonic-car- boxyl-hydrazide) chelating fiber. At flow rates of $1-8 \mathrm{~mL} /$ min, $\mathrm{Co}$ (II), $\mathrm{Cd}(\mathrm{II}), \mathrm{Pb}$ (II), $\mathrm{Ni}$ (II) and $\mathrm{Mn}(\mathrm{II})$ ions can be adsorbed quantitatively, while the adsorption of $\mathrm{Cu}(\mathrm{II})$, $\mathrm{Hg}$ (II) and $\mathrm{Zn}$ (II) ions had a decreasing dependency at a flow rate of $6 \mathrm{~mL} / \mathrm{min}$; but an $85 \%$ adsorption can be attained.

Effect of $\mathrm{pH}$ value on the adsorption

The $\mathrm{pH}$ value is one of the most important factors influencing the adsorption behavior of metal ions on the fi- 
Fig. 4 Effect of eluting velocity on the recovery of metal ions from PAAP-II chelating fiber column

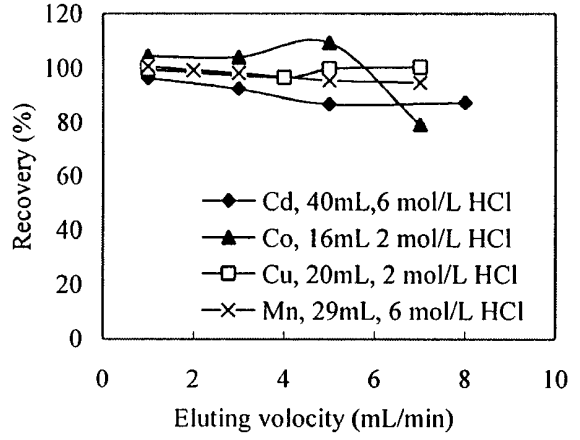

Table 1 The re-usability of PAAP-II chelating fiber

\begin{tabular}{|c|c|c|c|c|c|c|}
\hline \multicolumn{2}{|c|}{ Times } & \multicolumn{5}{|c|}{ Metal ions } \\
\hline & & \multirow{2}{*}{$\frac{\mathrm{Mn}(\mathrm{II})}{95.06}$} & \multirow{2}{*}{$\frac{\mathrm{Co}(\mathrm{II})}{100.0}$} & \multirow{2}{*}{$\frac{\mathrm{Ni}(\mathrm{II})}{95.03}$} & \multirow{2}{*}{$\frac{\mathrm{Cu}(\mathrm{II})}{100.0}$} & \multirow{2}{*}{$\frac{\mathrm{Cd}(\mathrm{II})}{100.0}$} \\
\hline 1 & Adsorption (\%) & & & & & \\
\hline & Recovery (\%) & 94.60 & 92.30 & 102.1 & 92.03 & 80.10 \\
\hline \multirow[t]{2}{*}{2} & Adsorption (\%) & 95.07 & 100.0 & 94.80 & 100.0 & 100.0 \\
\hline & Recovery (\%) & 98.50 & 97.25 & 107.9 & 96.50 & 86.20 \\
\hline \multirow[t]{2}{*}{3} & Adsorption (\%) & 95.07 & 100.0 & 97.07 & 100.0 & 100.0 \\
\hline & Recovery (\%) & 97.50 & 94.08 & 102.1 & 97.25 & 90.41 \\
\hline \multirow[t]{2}{*}{4} & Adsorption (\%) & 95.14 & 100.0 & 97.32 & 100.0 & 100.0 \\
\hline & Recovery (\%) & 98.50 & 91.82 & 112.8 & 92.73 & 92.22 \\
\hline \multirow[t]{2}{*}{5} & Adsorption (\%) & 95.00 & 100.0 & 95.58 & 100.0 & 100.0 \\
\hline & Recovery (\%) & 96.53 & 95.41 & 94.69 & 93.04 & 91.02 \\
\hline \multirow[t]{2}{*}{6} & Adsorption (\%) & 95.12 & 100.0 & 96.70 & 100.0 & 100.0 \\
\hline & Recovery (\%) & 95.82 & 92.92 & 103.3 & 93.14 & 87.23 \\
\hline \multirow[t]{2}{*}{7} & Adsorption (\%) & 94.94 & 100.0 & 96.35 & 100.0 & 100.0 \\
\hline & Recovery (\%) & 99.88 & 98.01 & 98.30 & 91.02 & 90.67 \\
\hline \multirow[t]{2}{*}{8} & Adsorption (\%) & 95.05 & 100.0 & 94.25 & 100.0 & 100.0 \\
\hline & Recovery (\%) & 98.50 & 92.24 & 102.1 & 93.42 & 91.87 \\
\hline \multirow[t]{2}{*}{9} & Adsorption (\%) & 95.01 & 100.0 & 96.90 & 100.0 & 100.0 \\
\hline & Recovery (\%) & 96.95 & 92.89 & 105.0 & 96.85 & 89.55 \\
\hline \multirow[t]{2}{*}{10} & Adsorption (\%) & 95.11 & 100.0 & 97.18 & 100.0 & 100.0 \\
\hline & Recovery (\%) & 98.50 & 97.63 & 102.1 & 92.06 & 88.33 \\
\hline
\end{tabular}

Table 2 Effect of interfering ions $(\mathrm{Na}, \mathrm{K}, \mathrm{Ca}, \mathrm{Mg})$ on the recovery of metal ions

\begin{tabular}{lccccc}
\hline $\begin{array}{l}\text { Conc.(mg/L) of } \\
\mathrm{Na}, \mathrm{K}, \mathrm{Ca}, \mathrm{Mg}\end{array}$ & \multicolumn{5}{l}{ Recovery $(\%)^{\mathrm{a}}$} \\
\cline { 2 - 6 } & $\mathrm{Zn}(\mathrm{II})$ & $\mathrm{Cd}(\mathrm{II})$ & $\mathrm{Ni}(\mathrm{II})$ & $\mathrm{Mn}(\mathrm{II})$ & $\mathrm{Co}(\mathrm{II})$ \\
\hline 100 & 102.1 & 94.50 & 99.01 & 95.47 & 98.21 \\
200 & 100.3 & 96.32 & 101.3 & 97.82 & 97.30 \\
\hline
\end{tabular}

a The concentration of $\mathrm{Zn}(\mathrm{II}), \mathrm{Cd}(\mathrm{II}), \mathrm{Ni}(\mathrm{II}), \mathrm{Mn}(\mathrm{II}), \mathrm{Co}(\mathrm{II})$ ions is $0.2 \mathrm{mg} / \mathrm{L}$

brous sorbent. The results in Fig. 2 show that these curves for $\mathrm{Cu}(\mathrm{II}), \mathrm{Pb}(\mathrm{II}), \mathrm{Cd}(\mathrm{II}), \mathrm{Zn}(\mathrm{II}), \mathrm{Ni}(\mathrm{II}), \mathrm{Mn}(\mathrm{II})$ and $\mathrm{Co}(\mathrm{II})$ exhibit a similar dependency on the $\mathrm{pH}$ value. For $\mathrm{Cu}(\mathrm{II})$ ion, the adsorption percentages were $99 \%$ above $\mathrm{pH} 3.0$ and decreased rapidly in the $\mathrm{pH}$ range $1.0-3.0$, while below $\mathrm{pH} 1.0 \mathrm{Cu}$ (II) ion was scarcely adsorbed by the
PAAP-II fiber. The adsorption percentages of $\mathrm{Pb}(\mathrm{II})$ and $\mathrm{Cd}(\mathrm{II})$ ions by the sorbent reached $98 \%$ above $\mathrm{pH} 3.5$. $\mathrm{Zn}(\mathrm{II}), \mathrm{Mn}$ (II) and $\mathrm{Co}(\mathrm{II}), \mathrm{Ni}(\mathrm{II})$ ions can be quantitatively adsorbed by the sorbent separately at $\mathrm{pH} 4.0,4.5,5.0$.

However, one interesting difference was observed in the case of the adsorption of $\mathrm{Hg}$ (II) ion by the PAAP-II fiber. The adsorption percentage of $\mathrm{Hg}(\mathrm{II})$ ion remained above $95 \%$ even at lower $\mathrm{pH}$ value $(\mathrm{pH}=1.5)$. This phenomenon is mainly contributed to the formation of a stable complex between the PAAP-II fiber and $\mathrm{Hg}$ (II) ion at lower $\mathrm{pH}$ value. Further investigations on the macromolecular structure and morphology of the PAAP-II fiber as well as on the coordination mechanism seem to be necessary for a better understanding of the property.

\section{Eluent acidity and volume for desorption}

The effects of the concentration and volume of hydrochloric or nitric acid on the desorption efficiency (recovery) of the metal ions from the chelating fiber column were investigated and the results are plotted in Fig. 3. All investigated metal ions showed a common trend to higher recovery at higher acidity and larger eluent volume of hydrochloric or nitric acid. Evidently, $\mathrm{Cu}(\mathrm{II}), \mathrm{Co}(\mathrm{II}), \mathrm{Zn}$ (II) and $\mathrm{Ni}(\mathrm{II})$ ions can be desorbed quantitatively with $15 \mathrm{~mL}$ of $2 \mathrm{~mol} / \mathrm{L}$ hydrochloric acid from the column with $98 \%$ recovery. The recovery of $\mathrm{Mn}$ (II) and $\mathrm{Cd}$ (II) ions in $25 \mathrm{~mL}$ and $35 \mathrm{~mL}$ of $6 \mathrm{~mol} / \mathrm{L}$ hydrochloric acid reached 96 and $90 \%$, respectively. However, dilute hydrochloric acid was not as effective as dilute nitric acid for the recovery of $\mathrm{Pb}$ (II) and $\mathrm{Hg}(\mathrm{II})$ ions, which was $98 \%$ in $25 \mathrm{~mL}$ of $4 \mathrm{~mol} / \mathrm{L}$ and $8 \mathrm{~mol} / \mathrm{L}$ nitric acid, respectively.

\section{Eluting velocity}

The influence of elution velocity on the recovery of $\mathrm{Cu}(\mathrm{II}), \mathrm{Pb}(\mathrm{II}), \mathrm{Zn}(\mathrm{II}), \mathrm{Cd}(\mathrm{II}), \mathrm{Mn}(\mathrm{II}), \mathrm{Ni}(\mathrm{II}), \mathrm{Co}(\mathrm{II})$ and $\mathrm{Hg}$ (II) was studied under optimum eluent acidity and volume (see Fig. 4). The results revealed that eluting velocity variation in the range of $1-8 \mathrm{~mL} / \mathrm{min}$ had no significant effect on the recovery of $\mathrm{Cu}(\mathrm{II}), \mathrm{Pb}(\mathrm{II}), \mathrm{Zn}$ (II), $\mathrm{Mn}$ (II), $\mathrm{Ni}(\mathrm{II})$ and $\mathrm{Hg}(\mathrm{II})$ and reached a recovery of $95 \%$ or more. But with respect to $\mathrm{Cd}(\mathrm{II})$ and $\mathrm{Co}(\mathrm{II})$ ions, the recovery decreased with increasing eluting rate. 
Table 3 The recovery of trace amount elements from model solution samples

a Average of 4 determinations with $95 \%$ confidence level

\begin{tabular}{llllllll}
\hline Elements & \multicolumn{2}{l}{ Added $(\mu \mathrm{g})$} & Found $(\mu \mathrm{g})$ & & & Average & Recovery $(\%)^{\mathrm{a}}$ \\
\hline $\mathrm{Mn}(\mathrm{II})$ & 18.08 & 18.80 & 18.33 & 19.30 & 18.65 & 18.77 & $103.8 \pm 3.5$ \\
$\mathrm{Co}(\mathrm{II})$ & 15.62 & 16.00 & 15.02 & 16.07 & 16.68 & 15.94 & $102.0 \pm 6.9$ \\
$\mathrm{Cd}(\mathrm{II})$ & 17.40 & 16.59 & 17.17 & 17.03 & 17.93 & 17.18 & $98.70 \pm 5.09$ \\
$\mathrm{Ni}(\mathrm{II})$ & 18.89 & 19.58 & 18.70 & 19.51 & 19.27 & 19.27 & $102.0 \pm 4.0$ \\
$\mathrm{Zn}(\mathrm{II})$ & 16.75 & 17.22 & 16.01 & 17.56 & 16.03 & 16.71 & $99.80 \pm 7.60$ \\
\hline
\end{tabular}

Stability and re-use of the fiber

After the dry chelating fiber had been stored at room temperature for about 2 years, the fiber was prepared by passing it through $1 \% \mathrm{NaOH}$ solution and washing with deionized water until neutral, and then the column was repeatedly used ten times according to the re-use procedure. The results in Table 1 showed that for $\mathrm{Mn}(\mathrm{II}), \mathrm{Co}(\mathrm{II})$, $\mathrm{Ni}(\mathrm{II}), \mathrm{Cu}(\mathrm{II})$ and $\mathrm{Cd}(\mathrm{II})$ ions, quantitative extraction (> 95\%) was observed. However, except for Cd(II), the recovery of the other metal ions eluted with $30 \mathrm{~mL}$ of $6 \mathrm{~mol} / \mathrm{L}$ hydrochloric acid from the chelating fiber column was above $90 \%$. In addition, swell of the chelating fiber was not found after using it ten times.

Effect of interfering ions on the recovery of metal ions

In order to evaluate the possibility of selective recovery of $\mathrm{Co}(\mathrm{II}), \mathrm{Cd}(\mathrm{II}), \mathrm{Mn}(\mathrm{II}), \mathrm{Zn}(\mathrm{II})$ and $\mathrm{Ni}(\mathrm{II})$ ions in the presence of interfering ions, 10-20 mg each of $\mathrm{Na}, \mathrm{K}, \mathrm{Ca}, \mathrm{Mg}$ ions as their chloride salts were added to a $100 \mathrm{~mL}$ mixed solution containing $20 \mu \mathrm{g}$ each of the mentioned ions. The results, given in Table 2 , showed that 1000 -fold excesses of $\mathrm{Na}, \mathrm{K}, \mathrm{Ca}, \mathrm{Mg}$ caused little interference with the recovery of the tested metal ions.

Preconcentration of trace amount elements from solution samples

A large $1 \mathrm{~L}$ volume of model solution samples, containing 15-20 $\mu \mathrm{g}$ each of $\mathrm{Co}(\mathrm{II}), \mathrm{Cd}(\mathrm{II}), \mathrm{Mn}(\mathrm{II}), \mathrm{Zn}(\mathrm{II})$ and $\mathrm{Ni}(\mathrm{II})$, was prepared for evaluating the possibility of enriching solution of low concentration. The results listed in Table 3 show that the amount of the metal ions detected after preconcentration and recovery by this technique is basically in agreement with the added value and the recovery of the added elements with $95 \%$ confidence level is in the range $92-109 \%$. Clearly, this method offers a good precision.

\section{Conclusion}

The poly(acrylaminophosphonic-carboxyl-hydrazide) chelating fiber shows good stability, fast adsorption and elution rate, and can be re-used efficiently. Above $\mathrm{pH} 5.0, \mathrm{Cu}(\mathrm{II})$,
$\mathrm{Pb}$ (II), $\mathrm{Zn}$ (II), $\mathrm{Cd}(\mathrm{II}), \mathrm{Mn}$ (II), Ni(II), $\mathrm{Co}$ (II) and $\mathrm{Hg}$ (II) ions can be quantitatively adsorbed by the PAAP-II chelating fiber and the adsorbed ions can be desorbed under adequate eluting conditions. The column packed with the PAAP-II chelating fiber provides a very simple, rapid and reliable technique for the preconcentration of trace amounts of $\mathrm{Mn}(\mathrm{II}), \mathrm{Co}(\mathrm{II}), \mathrm{Cd}(\mathrm{II}), \mathrm{Ni}(\mathrm{II})$ and $\mathrm{Zn}$ (II) ions from the model solution samples with satisfactory results and is expected to be applicable to real samples.

Acknowledgement This work was supported by SKLEAC and Key Project of Resource and Eco-Environmental Research in the Chinese Academy of Sciences (No: KZ 952-S1-231).

\section{References}

1.Zolotov YuA, Kuzmin NM (1982) Preconcentration of Microelements, Khimia, Moscow (in Russian)

2. Marhol M (1982) Ion Exchangers in Analytical Chemistry, Academia, Prague

3. Myasoedova GV, Antokol'skaya II, Savvin SB (1985) Talanta 32: 1105

4. Chang XJ, Su ZX, Zhan GY, Luo XY (1990) Chin J Chem 48 : 157

5. Chang XJ, Li YF, Luo XY, Zhan GY, Su ZX (1991) Anal Chim Acta $245: 13$

6. Chang XJ, Luo XY, Zhan GY, Su ZX (1992) Talanta 39:937

7. Su ZX, Chang XJ, Xu KL, Luo XY, Zhan GY (1992) Anal Chim Acta 268:323

8. Luo XY, Su ZX, Zhan GY, Chang XJ (1992) Ion Exch Adsorpt $8: 34$

9. Myasoedova GV, Savvin SB, Makarova SB (1970) Zh Anal Khim 25: 1859

10. Burba P, Lieser KH (1977) Fresenius Z Anal Chem 286: 191

11. Burba P, Lieser KH (1979) Fresenius Z Anal Chem 298:373

12. Donina Bilba, Simon Fisel (1974) Mikrochim Acta (6):985

13. Yoshikuni N, Kuroda R (1977) Talanta 24:163

14. Yu MQ, Liu GQ (1981) Acta Scientiae Circumstantiae $1: 180$

15. Myasoedova GV, Antokol'skaya II, Kubrakova IV, Belova EV, Mezhirov MS (1986) Zh Anal Khim 41:1816

16. Myasoedova GV, Antokol'skaya II, Shvoeva OP, Mezhirov MS, Savvin SB (1988) Solvent Extr Ion Exch 6:301

17. Zhang YX, Wang CM, Qu YM (1984) Mikrochim Acta I (3-4): 291

18. Su ZX, Luo XY, Chang XJ (1989) J Lanzhou University 25 : 73

19. Chang XJ, Luo XY, Zhan GY, Su ZX (1990) J Lanzhou University $26: 35$

20. Chang XJ, Luo XY, Zhan GY, Su ZX (1990) Mikrochim Acta I (1-2): 101

21. Chang XJ, Su ZX, Zhan GY, Luo XY, Gao WY (1994) Analyst 119: 1445

22. Chang XJ, Su ZX, Luo XY, Zhan GY (1993) Talanta 40:527

23. Liu RX, Zhang BW, Tang HX (1998) Reactive polymers (in press) 